\title{
Application of Thermal Analysis to Breeding Fruit Crops for Increased Cold Hardiness
}

\author{
H.A. Quamme \\ Agriculture Canada, Research Station, Summerland, British Columbia VOH 1ZO, Canada
}

Knowledge of the mechanisms by which plants survive freezing is important to cultivar improvement through breeding and selection. It enables the choice of appropriate measurement techniques, selection of germplasm sources to use as parents, and the identification of offspring with superior hardiness. Knowledge of plant survival mechanisms can also lead to the development of new techniques that allow more rapid measurement of plant hardiness than those presently used.

The freezing process in plants is a well-studied phenomenon (Levitt, 1956; Olien, 1981; Sakai and Larcher, 1987). In short, cell solutes depress the freezing point of cells, but generally this confers only a few degrees of protection. Most plants supercool below their freezing point. This supercooling is transitory but maybe a protective mechanism in tender plants (usually to no more than - SC). Many tender plants are injured when ice first forms in the tissue as a result of intracellular freezing. If ice penetrates the cytoplasm, death almost always occurs. However, many plants capable of hardening have the capacity to resist freezing injury by extracellular freezing. During the course of extracellular freezing, ice first forms in the extracellular spaces. Water is withdrawn from the cell due to lower vapor pressure over ice. The membrane and cell walls of hardy cells resist ice penetration. Plant cells may be injured by dehydration or by mechanical effects that occur during the course of extracellular freezing. The degree of tolerance to extracellular freezing varies from the capability to survive only initial freezing to that of surviving in liquid nitrogen $(-196 \mathrm{C})$.

Certain tissues, such as axial and ray parenchyma cells and flower buds, of many woody plants and some seeds do not exhibit normal extracellular freezing, but retain water against the vapor pressure gradient after freezing is initiated in the plant (Burke et al., 1976). Water entrapped in cells of these tissues supercools to the temperature at which ice explosively spreads from the surrounding tissue into the cell (heterogeneous nucleation) or to the temperature at which the cellular water becomes internally unstable and spontaneously freezes (homogeneous nucleation). Some cells can remain in the deep supercooled state throughout the winter. The depth and stability of this supercooling distinguishes it from the transitory supercooling that occurs just below freezing, and for this reason, it has been termed deep supercooling. The freezing of water in deep supercooled tissue releases heat of fusion that can be detected on the thermal profile during cooling as low-temperature (LT) exotherms (Fig. 1 A and B). The occurrence of deep supercooling in fruit crops, its measurement by thermal analysis, and application of thermal analysis to breeding fruit crops for increased cold hardiness will be discussed here.

The expression of deep supercooling varies with tissue and species. It is characteristic of some woody plants, mainly deciduous hardwoods. Many woody plants do not exhibit deep supercooling. These include tender evergreens, such as citrus, but also include plants capable of hardening to extremely low temperatures, such as willows, birch, and alder (Burke et al., 1976). Deep supercooling also has not been detected in herbaceous plants.

Deep supercooling occurs in more than 240 species in 33 families of angiosperms and one family of gymnosperm (Quamme, 1985). Many deciduous fruit crops, including apple, apricot, blackberry, blueberry, cherry, grape, peach, pear, plum, and raspberry, exhibit deep supercooling (Table 1). In most of these crops, deep supercooling is exhibited in xylem tissues and, in many, in flower bud tissues. only in grape has direct evidence been found of deep su- percooling in bark tissues and vegetative buds (Pierquet and Stushnoff, 1980). However, in other fruit crops, injury to the bark and vegetative buds is often closely associated with the LT exotherm. Injury often extends from the xylem ray parenchyma into the phloem and vegetative buds depending on the stage of acclimation and on the cooling rate (Quamme et al, 1972a). Possibly, some of the cells close to the xylem ray parenchyma express some degree of deep supercooling that is difficult to detect with present techniques.

The nature of the deep supercooling phenomenon is not yet clearly understood. Structural features of the tissue are involved in both the xylem ray parenchyma and the flower buds. In the xylem ray parenchyma cells, the cell wall structure appears to be important in maintenance of supercooling within the cell. Apparently, the cell wall structure surrounding the rays prevents the cell collapse due to the vapor pressure difference between ice and supercooled water (George and Burke, 1977; Quamme et al., 1973). A barrier to water permeability formed at the pit membrane may also prevent water loss from the cell and seeding of the cell from the exterior (Wisniewski et al., 1987). In the flower bud, the floral tissue, which deep supercools, tends to have small cells with numerous small vacuoles and lacks intracellular spaces that may prevent the spread of ice (Ashworth, 1984). In peach, a dry region is formed by water migration to the scales during the initial stages of freezing that appears to prevent the ice from spreading into the flower (Quamme, 1978). Lower water potential of the flower may also help prevent ice from spreading into the flower during the initial stages of freezing (Quamme and Gusts, 1987).

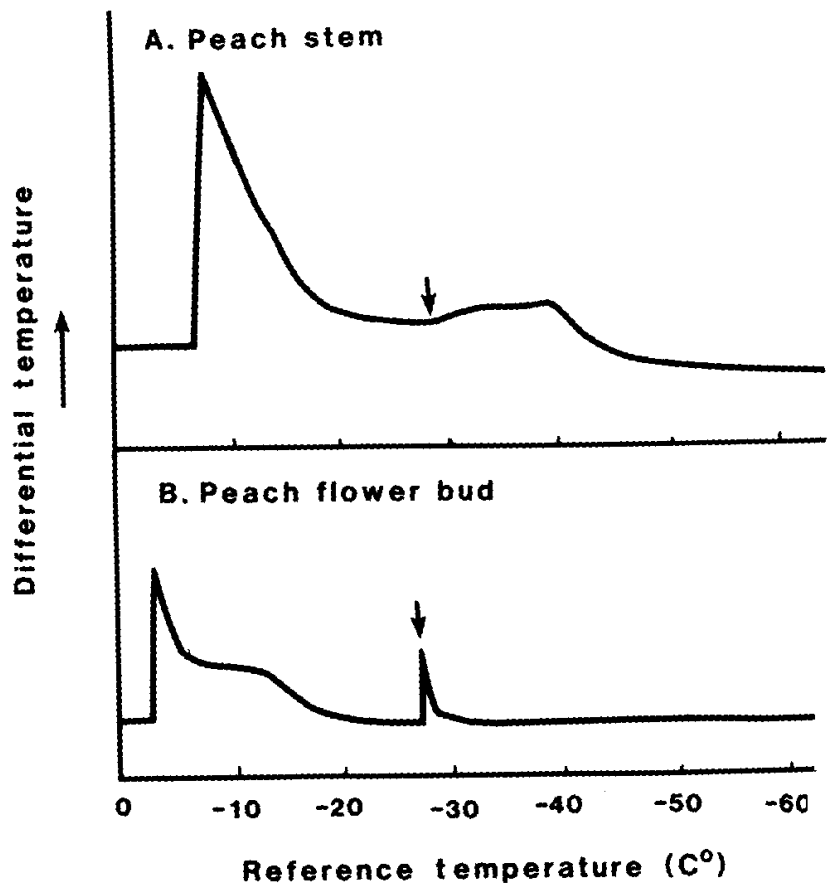

Fig. 1. Typical differential thermal profiles of (A) a 'Redhaven' peach stem section and (B) a 'Redhaven' peach flower bud. The $\mathrm{Y}$ axis indicates the differential temperature between the sample and a dry reference the $\mathrm{X}$ axis indicates the temperature of the reference. The initiation of the low-temperature exotherm is indicated by an arrow. 


\begin{tabular}{|c|c|c|c|}
\hline Crop & Genus and species & Tissue $^{\mathbf{z}}$ & Reference \\
\hline Apple & Malus domestica (Borkh.) & $\mathrm{X}$ & Quamme, 1976; Quamme et al., 1972a \\
\hline Apricot & Prunus armeniaca $\mathrm{L}$. & $\mathrm{X}, \mathrm{FB}$ & $\begin{array}{l}\text { Ashworth, 1984; Ashworth et al., 1981, 1983; } \\
\text { Quamme, 1974; Quamme et al., 1982b }\end{array}$ \\
\hline Blackberry & Rubus spp. & FB & Warmund et al., 1988 \\
\hline Blueberry & Vaccinium corymbosum $\mathrm{L}$. & $\mathrm{X}, \mathrm{FB}$ & Bierman et al., 1979; Quamme et al., 1972b \\
\hline Cherry & Prunus avium $\mathrm{L}$. & $\mathrm{X}, \mathrm{FB}$ & $\begin{array}{l}\text { Andrews et al., 1983; Quamme, 1974; } \\
\text { Quamme et al., 1982b }\end{array}$ \\
\hline Grape & $\begin{array}{l}\text { Prunus cerasus L. } \\
\text { Vitis sp. }\end{array}$ & $\begin{array}{l}\mathrm{X}, \mathrm{FB} \\
\mathrm{Ph}, \mathrm{X}, \mathrm{B}\end{array}$ & $\begin{array}{l}\text { Quamme et al., 1982b } \\
\text { Andrews et al., 1984; Pierquet and Stush- } \\
\text { noff, 1972; Quamme, 1986; Wolf and } \\
\text { Pool, 1987. }\end{array}$ \\
\hline Peach & Prunus persica (L.) Batch & $\mathrm{X}, \mathrm{FB}$ & $\begin{array}{l}\text { Proebsting and Sakai, 1979; Quamme, 1974; } \\
\text { Quamme et al., 1982a }\end{array}$ \\
\hline Pear & $\begin{array}{l}\text { Pyrus communis L. } \\
\text { Pyrus pyrifolia (Burm.) Nak. }\end{array}$ & $\begin{array}{l}\mathrm{X} \\
\mathrm{X}\end{array}$ & $\begin{array}{l}\text { Montano et al., 1987; Rajashekar and Burke, } \\
\text { 1978; Rajashekar et al., 1982; Quamme, } \\
\text { 1976 }\end{array}$ \\
\hline $\begin{array}{l}\text { Plum } \\
\text { Raspberry }\end{array}$ & $\begin{array}{l}\text { Prunus domestica } \mathrm{L} . \\
\text { Prunus salicina Lindl. } \\
\text { Rubus ideaus L. }\end{array}$ & $\begin{array}{l}X, F B \\
X, F B \\
X\end{array}$ & $\begin{array}{l}\text { Quamme, 1974; Quamme et al., } 1982 \mathrm{~b} \\
\text { Quamme, 1974; Quamme et al., } 1982 \mathrm{~b} \\
\text { H.A.Q., unpublished data }\end{array}$ \\
\hline
\end{tabular}

${ }^{2}$ Tissue type: $\mathrm{B}=$ vegetative bud, $\mathrm{FB}=$ flower bud, $\mathrm{X}=$ xylem, and $\mathrm{Ph}=$ phloem.

\section{Methodology of thermal analysis of plant tissue}

The simplest method used to measure the LT exotherm is to mount the tissue onto a single sensor, such as a thermocouple or thermistor, as shown for grape in Fig. 2A, and monitor temperature during the course of freezing. A simple time-temperature profile is effective for measuring the exotherm in buds in which the exotherm occurs as a sharp, discreet event. Single thermocouple sensors can be connected in series to monitor more than one flower bud on the same channel (Quamme et al., 1975).

Exotherms that occur over a broad temperature range are difficult to detect with single sensors on a time-temperature profile, especially if the rate of temperature drop is not constant or if the amount of heat released during freezing is small. Differential thermal analysis (DTA), in which the difference in temperature between a dry reference and the sample is measured and plotted against the reference temperature, is one way of improving the sensitivity for the detection of small exotherms (apparatus shown in Fig. 2B). The differential temperature can be amplified to increase sensitivity. Thermocouples are usually used for DTA, but Nus et al. (1981) and George (1982) describe sensitive methods for DTA using thermistors.

Thermopiles can also be used to measure differential temperature response and have the advantage of amplifying the signal. A thermoelectric module (Melcor Materials Electronic Products Corp., Trenton, N.J. ), which was designed as a cooling plate, is one type of thermopile that is both sensitive and inexpensive (Andrews et al., 1983). The thermocouple modules are made of sufficient size to measure several flower buds at once (Fig. 2C). Flower buds are placed on one side of the plate and dried reference samples are placed on the other side. Differential temperature across the plate can be read from the output of the plate, and exotherms appear as sharp peaks. The temperature of the plate is read with another temperature sensor. However, in my experience, it is often difficult to maintain constant temperature across the plate and thus prevent the basal differential temperature response from drifting during the course of freezing. Detection of small, broad exotherms is difficult when drift in the basal temperature response occurs.

Commercial scanning calorimeters that can be adapted to measure freezing in plant tissue during freezing use sensitive thermopiles to measure heat evolution. The sensitivity of scanning calorimeters is high, and the amount of ice formed can be quantified on the basis of the amount of heat of fusion that is released, but most commercial calorimeters are limited in the size of tissue that can be accommodated. Furthermore, the range of freezing rates at which the calorimeter can be operated is less than those desired for freezing plant tissue.

To prevent loss in temperature sensitivity and to maintain accuracy, care must be taken to ensure that the sensor is in thermal contact with the tissue. When mounting the tissue on the sensor,
A.
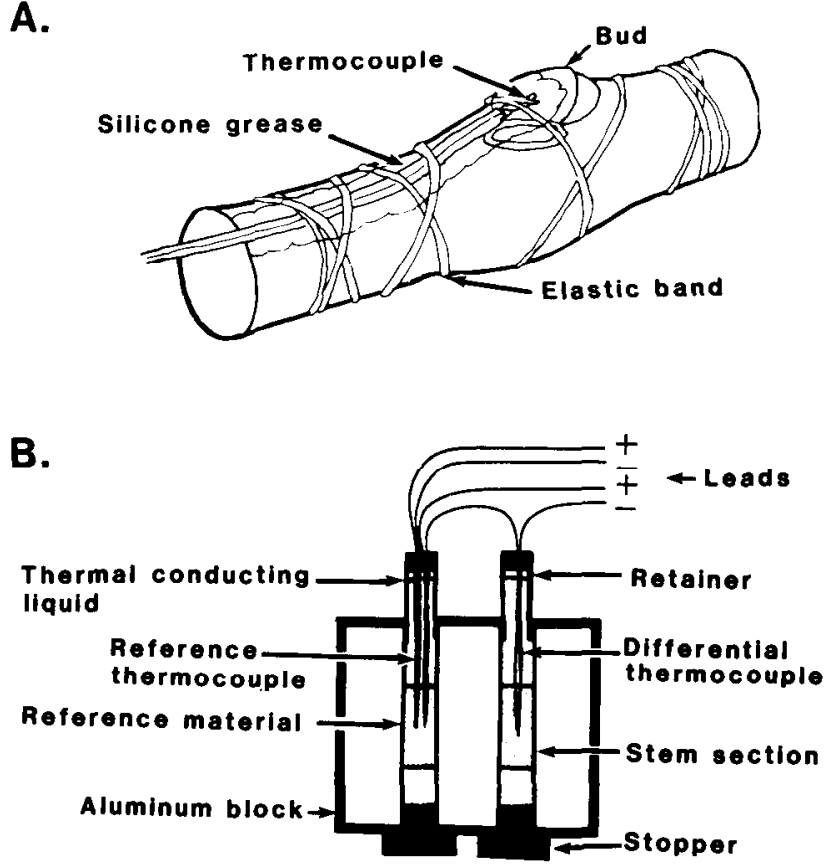

C.

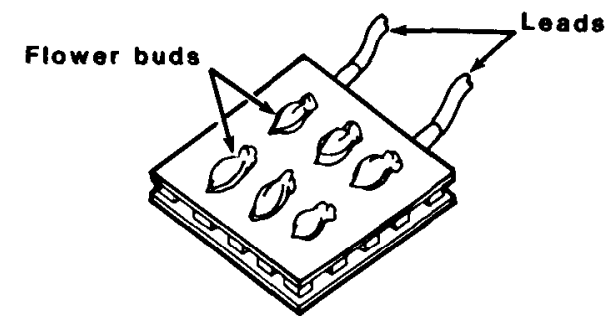

Fig. 2. Apparatus used for thermal analysis of plant tissue: (A) grape bud mounted on a thermocouple, (B) cross section of an aluminum block used for differential thermal analysis (DTA) of twig sections, and (C) thermopile plate for DTA of flower buds. Diagram in panel A from Quamme, 1986; diagram in panel B from Quamme et al., 1972a. 
the tissue should be attached tightly or, if possible, inserted into tissue. Thermal contact can be increased by applying silicon grease (Quamme, 1986) or a thermal conducting paste (e.g., Omegatherm, Omega Engineering, Stanford, Corm.) (Andrews et al., 1983) to the surfaces of the sensor and tissue that are in contact. If the cooling procedure is begun below $0 \mathrm{C}$, ice, which is a good thermal conductor, can be used to maintain thermal contact. Ice can be built up between the tissue and sensor with small droplets of ice water put in place with a tweezer or a fine pipette (Quamme, 1983).

Constant cooling rates are essential for thermal analysis. Temperature control in most freezing chambers is not precise enough for thermal analysis. When thermal analysis is conducted on buds using freezing chambers, temperature variation can be dampened by placing the tissue and sensor in a thermos bottle. DTA on stem tissue is often conducted using an aluminum block to dampen the temperature variation and to maintain a constant differential base temperature (Fig. 2B). Often, liquid fluorocarbon, mineral oil, or silicone oil is placed in the wells to provide thermal contact between the sample and the block (Quamme et al., 1972a). Liquid-controlled temperature baths can also be used to maintain constant temperature during freezing (George and Burke, 1977). Liquid nitrogen is often used to cool these baths to the required temperature.

For routine measurement of hardiness in breeding programs, the capability of conducting many measurements is required. The number of measurements in buds that have discreet LT exotherms can be increased by placing more buds on the sensor, but there is an upper limit because of the difficulty in distinguishing overlapping exotherms. It is necessary to use one sensor per sample of tissue when the exotherms are not discreet and are small, as is the case for those found in most stem tissues. The only way of increasing the number of measurements with these tissues is to increase the number of measurement channels. Fortunately, many computerdriven data-logging systems are now available that allow rapid temperature measurement in multichannel. Such systems are too numerous to list here, but many suppliers provide data-logging equipment that can be adapted to thermal analysis measurement.

\section{Use of thermal analysis to measure flower bud hardiness}

LT exotherms detected in the dormant flower buds of many Prunus species (Quamme, 1974) and blueberry (Bierman et al., 1979) and dormant mixed buds of grape (Pierquet and Stushnoff, 1980) appear as discreet events, and the initiation of the LT exotherm coincides with the killing point of the flower. In sweet and sour cherry, which have flower buds with multiple flowers, one LT exotherm is usually detected for each flower, producing a thermal profile with multiple exotherms (Quamme, 1974). The primary, secondary, and tertiary bud within the complex bud of grape each produce a LT exotherm that also results in a profile with multiple exotherms (Pierquet and Stushnoff, 1980).

The use of thermal analysis to measure differences in flower bud hardiness among peach (Proebsting and Sakai, 1979; Quamme, 1974) and grape cultivars (Andrews et al., 1984; Quamme, 1986) has been demonstrated. Potential also exists for its use in measuring flower bud hardiness of apricot (Ashworth et al., 1981), plum, sweet and sour cherry (Quamme, 1974), and blackberry (Warmund et al., 1988), but its use in these crops has not been determined fully. The use of thermal analysis, however, is not appropriate for measuring the flower bud hardiness of some crops. The flower buds of apples and pears do not exhibit an LT exotherm (Quamme, 1976). Ice forms in the flowers of both apple and pear and they appear to freeze extracellularly (H. A. Q., unpublished data).

There are several important considerations, however, in carrying out thermal analysis measurements on flower buds. These include excision point of the tissue, cooling rate, and preconditioning temperature. Flower buds are usually excised from the shoot before mounting on the sensor. In both grape (Quamme, 1986; Wolf and Pool, 1987) and peach (Proebsting and Sakai, 1979; Quamme, 1978), cutting the bud too close to the flower raised the LT exotherm temperature. Apparently, a structural feature of the bud that is required to maintain deep supercooling was destroyed. Migration of water from the base to the scales and decline of water content at the base of the flower during the initial stages of freezing appear to be necessary for full development of the capacity to supercool (Quamme, 1978). Cooling the flower buds at rates that exceeded $\approx 10 \mathrm{C} / \mathrm{hr}$ prevented deep supercooling (Ashworth, 1984; Proebsting and Sakai, 1979; Quamme, 1983). However, cooling grape buds at cooling rates of up to $40 \mathrm{C} / \mathrm{hr}$ did not raise the exotherm temperature. But at a cooling rate of $40 \mathrm{C} / \mathrm{hr}$, it was not possible to maintain equilibrium in temperature between the sensor and the tissue, which lead to an error in measurement. The LT exotherm temperature of grape was constant between cooling rates of 1.5 to $10 \mathrm{C} / \mathrm{hr}$ (Quamme, 1986). Preconditioning flower buds by exposure to freezing temperatures lowered the supercooling point in peach (Quamme, 1983) and grape (Pierquet and Stushnoff, 1980; Quamme, 1986). In peach, the supercooling point of the flower decreased as the water content of the flower decreased due to its migration to ice in surrounding tissue (Quamme, 1978, 1983). Cultivars responded differently to preconditioning temperatures and this may be used to improve cultivar separation. Exposure of buds to low temperatures $(-5 \mathrm{C}$ for 10 days, then $-10 \mathrm{C}$ for 3 days) improved the separation of three grape cultivars in autumn when they were similar in hardiness, but not in midwinter after they had already been exposed to low environmental temperatures (Quamme, 1986).

The presence of dead buds that may occur as a result of natural freezing can affect measurements of hardiness levels using thermal analysis. For example, the LT exotherm of living peach flower buds is usually distributed about the mean below $-17 \mathrm{C}$, whereas the LT exotherm of dead flowers will be distributed at about - 10C (Quamme, 1978). In this case, deviation of the LT exotherm temperature of dead buds from that of live buds is great enough to warrant their exclusion from the LT exotherm measurement.

\section{Use of thermal analysis to measure the hardiness of stem tissue}

LT exotherms of stem tissue that are produced by freezing of the xylem parenchyma cells are broad and occur over a wide temperature range. Heat release is often low; thus, sensitive methods of DTA or heat calorimetry must be used to detect them. Neither method is readily adaptable to large-scale measurement. Furthermore, it has been difficult to maintain a constant temperature drop at slow rates of cooling $(5 \mathrm{C} / \mathrm{hr}$ or less). As a result, most thermal analyses have been conducted at cooling rates $(15 \mathrm{C} / \mathrm{hr}$ or greater) that are more rapid than those that occur in nature.

The validity of measurements made at rapid rates rests on their correlation with injury tests conducted at slower rates. For the most part, agreement between the temperature determined at rapid cooling rates and xylem damage determined at slow cooking rates has been good (Quamme et al., 1973). Although the shape of the DTA profiles of apple varies with stage of acclimation, the temperature at which deep supercooling is initiated and at which xylem injury occurs is constant with cooling rate (Quamme et al., 1972a). The independence of deep supercooling in the xylem from cooling rate has also been observed in many Prunus (Quamme et al., 1982b; Rajashekar and Burke, 1978) and Pyrus species (Quamme, 1976; Rajashekar and Burke, 1978; Rajashekar et al., 1982).

Thermal analysis is useful for measuring the hardiness of the xylem, but it does not always provide a measure of vegetative bud and bark hardiness, both of which are considered to be more critical to survival than xylem hardiness. In apple, damage to the phloem and cambium tissues coincided with the initiation of the LT exotherm in early autumn and spring, but bark tissues survived to below this temperature in midwinter (Quamme et al., 1972a). In peach, however, injury to phloem and cambium tissues in midwinter occurred at about the same temperature as the LT exotherm (Quamme et al., 1982a). Vegetative buds of hardy apple cultivars Haralson and Dolgo also survived to below the initiation temperature of the LT exotherm at three cooling rates $(90,20$, and $3 \mathrm{C} / \mathrm{hr})$, whereas the vegetative buds of the susceptible cultivar Starkrimson Red Delicious survived to below the initiation temperature of the LT exotherm only at the two slower cooling rates. At $90 \mathrm{C} / \mathrm{hr}$, vegetative buds of 'Starkrimson Red Delicious' survived to the initiation temperature of the LT exotherm (Quamme et al., 1972a). The rate effect 
in vegetative bud cells was probably due to insufficient equilibration of intracellular water with extracellular ice, and this effect appears to vary with cultivar.

In spite of lack of correlation of the LT exotherm with tissues other than the xylem, LT exotherm measurements often are closely related to relative rank in plant survival among different cultivars and species. Close relationship between LT exotherm measurements and relative plant hardiness have been observed among species of Prunus (Montano et al., 1982; Quamme et al., 1982b; Rajashekar and Burke, 1978), Pyrus (Rajashekar et al., 1982), and Malus, and among cultivars of Malus spp. (Quamme, 1976), Prunus persica, Prunus armeniaca (Quamme et al., 1982b), and Pyrus communis (Quamme, 1976).

A comparison of thermal analysis with visual scores of browning and with conductivity measurements among three apple cultivars is shown in Table 2 . The rank of cultivars by the initiation temperature of the LT exotherm and the end of the LT exotherm agreed with the rank in known hardiness, rank in hardiness measured by visual scoring, and rank in hardiness measured by the conductivity method. Statistical separation of the cultivar hardiness by the LT exotherm analysis was about as good as by visual scores or by the conductivity method.

Implications of deep supercooling to breeding fruit crops for winter hardiness

The findings that deep supercooling occurs in plants have important implications for breeding of improved cold hardiness other than improvement in measurement technique. There appears to be a close relationship between the capacity to deep supercool in many deciduous woody plants and their geographical distribution. Many native deciduous hardwoods that deep supercool to about the homogeneous nucleation temperature of water $(-38 \mathrm{C})$ are limited in their northern distribution to about the $-40 \mathrm{C}$ minimum temperature isotherm. Other, hardier species that do not deep supercool have a more northern distribution (George et al., 1974). Many fruit crops also are restricted in their range because of their limited capacity to deep supercool (Pierquet and Stushnoff, 1980; Quamme, 1976; Quamme et al., 1982b). In considering extension of the production of these crops into colder regions through breeding for cold hardiness, knowledge of the mechanisms of deep supercooling in these plants is necessary. For example, knowledge of the cell wall features that are required for expression of the deep supercooling characteristic in the ray parenchyma may lead to knowledge of the biochemical reactions controlling its development and ultimately to its manipulation through genetic engineering.
The deep supercooling phenomenon appears to be an avoidance mechanism for low-temperature survival, For example, peach flowers that have been excised from the flower bud and frozen at $1 \mathrm{C} /$ hr survive to only $-7 \mathrm{C}$ if seeded with ice and to only $-10 \mathrm{C}$ if left unseeded, whereas they freeze at $-18 \mathrm{C}$ in the intact flower bud at the same freezing rate (H.A.Q., unpublished data). Ray parenchyma cells of hickory freeze intracellularly, not extracellularly, and if excised in thin sections, they do not supercool to as low a temperature as that observed in unsectioned stem pieces (George and Burke, 1977).

Although some tissues appear to avoid freezing by deep supercooling, the degree of protection is limited in comparison to that which occurs in tissues that freeze extracellularly, often in the same plant. For example, in peach flower buds, the scales and other tissue subtending the flower, which freeze extracellularly, survive to temperatures below that of the flower (Quamme, 1978). The bark and leaf bud tissues in several species, including apple, pear (Quamme, 1976), cherry, and plum (Quamme et al., 1975), are capable of surviving below the homogeneous nucleation temperature, whereas xylem tissue is killed at this temperature. In apple, leaf buds and bark tissues can be cooled to liquid nitrogen temperatures without injury, but the xylem is invariably injured (Sakai, 1965).

It is not clear why deep supercooling has evolved in some species but not in others as a survival mechanism to protect certain tissues. But, it is possible that deep supercooling has co-evolved with some other important adaptation of these species. Although evidence is lacking, one can speculate as to what these adaptations might be. Lack of hardiness in the floral tissue of peach that survives by deep supercooling may be linked to early flower development in the spring. In turn, early flower development may be a requirement for early ripening of the fruit. It is unclear if supercooling of the ray parenchyma is linked to some other physiological feature that confers an adaptive advantage. But deep supercooling has been found in species that tend to have a ring porous structure (George et al., 1974), which, perhaps, confers a higher rate of water conductivity than that found in species that are not ring porous.

Further research is necessary to test these hypotheses, but if true, the knowledge would have important implications to establishing goals in fruit breeding programs. Such additional information might explain why it has not always been possible to achieve major genetic improvements in cold resistance of some fruit crops, e.g., peach; the selection for cold hardiness may result in the selection against some other important characteristic. With more knowledge, it might be possible to plan better strategies for overcoming some of these barriers to the improvement of cold hardiness in fruit crops through breeding.

Table 2. Comparison of the stem tissues of three apple cultivars by exotherm analysis conducted at $30 \mathrm{C} / \mathrm{hr}$ by scoring visual injury of phloem and xylem of shoot sections frozen to $-39 \mathrm{C}$ at $1 \mathrm{C} / \mathrm{hr}$ and by measuring the conductivity index on the same sections that were visually scored.

\begin{tabular}{|c|c|c|c|c|c|}
\hline \multirow[b]{2}{*}{ Cultivar } & \multicolumn{2}{|c|}{$\underline{\text { Low-temp exotherm }\left({ }^{\circ} \mathrm{C}\right)}$} & \multicolumn{2}{|c|}{$\begin{array}{c}\text { Visual injury }{ }^{x} \\
(0-5)\end{array}$} & \multirow[b]{2}{*}{$\begin{array}{l}\text { Conductivity } \\
\text { index }(\%)^{w}\end{array}$} \\
\hline & $\begin{array}{l}\text { Initiation } \\
\text { temp }\end{array}$ & $\begin{array}{l}\text { End } \\
\text { temp }\end{array}$ & $\begin{array}{l}\text { Phloem- } \\
\text { cambium }\end{array}$ & Xylem & \\
\hline \multicolumn{6}{|l|}{ Golden } \\
\hline Delicious & $-34.1 \mathrm{a}^{\mathrm{w}}$ & $-38.7 \mathrm{a}$ & $2.2 \mathrm{a}$ & $3.2 \mathrm{a}$ & $15 \mathrm{a}$ \\
\hline \multicolumn{6}{|l|}{ Summerland } \\
\hline Red McIntosh & $-34.5 \mathrm{a}$ & -39.8 a & $0.4 \mathrm{~b}$ & $2.2 \mathrm{a}$ & $3 \mathrm{~b}$ \\
\hline Heyer 12 & $-37.2 b$ & $-45.4 b$ & $0.0 \mathrm{~b}$ & $0.5 \mathrm{~b}$ & $0 \mathrm{c}$ \\
\hline $\mathrm{SE}$ & \pm 0.9 & \pm 0.9 & \pm 0.1 & \pm 0.2 & \\
\hline No. of measurements & 6 & 6 & 4 & 4 & 4 \\
\hline
\end{tabular}

"The samples were collected from mature trees 4 Jan. 1988.

'Mean separation in columns by Tukey's range test, $P=0.05$.

${ }^{x}$ Cross sections of the shoot piece were scored visually for browning. A score was assigned to the phloem-cambium region and to the xylem, depending on the degree of browning, as follows: $\mathrm{O}=$ no browning, $1=$ trace of browning, $2=$ one-half of tissue showing browning, $3=$ all of tissue showing browning, $4=$ all of tissue showing intense browning, and $5=$ all of tissue showing extremely intense browning.

"Conductivity index $=$ Conductivity of sample - conductivity of control $\times 100 /$ conductivity of boiled sample - conductivity of control. Conductivity measurements were made on leachates (weight of water $=5 \times$ the weight of tissue) after $24 \mathrm{hr}$ of leaching. An arcsin transformation was made on the conductivity index data before analysis of variance and Tukey's range tests were performed. The standard error was not included in the table. 


\section{CONCLUSIONS}

The discovery of the occurrence of deep supercooling in many of the deciduous fruit crops is of importance for the improvement of cold hardiness of these crops by breeding. It has allowed development of thermal analysis for rapid measurement of cold hardiness in some, but not all, tissues of these crops. Further research on this phenomenon should provide knowledge of the genetic barriers that prevent cold-hardiness improvement in these crops and should allow breeders to devise approaches for overcoming them. Ultimately, it may lead to the extension of the northern range of these crops and decrease the risk of freezing injury in regions where they are presently grown.

\section{Literature Cited}

Andrews, P. K., E.L. Proebsting, and G.S. Campbell. 1983. An exotherm sensor for measuring the cold hardiness of deep supercooled flower buds by differential thermal and analysis. HortScience 18:77-78.

Andrews, P. K., C.R. Sandridge, and T.K. Toyoma. 1984. Deep supercooling of dormant reacclimating Vitis buds. J. Amer. Enol. Vitic. 35:175177.

Ashworth, E.M. 1984. Xylem development in Prunus flower buds and relationships to deep supercooling. Plant Physiol. 74:862-865.

Ashworth, E. M., G.W. Lightener, and D.J. Rowse. 1981. Evaluation of apricot flower bud hardiness using a computer-assisted method of thermal analysis. HortScience 16:754-756.

Ashworth, E. M., D.J. Rowse, and L.A. Billmyer. 1983. The freezing of water in woody tissues of apricot and peach and the relationship to freezing injury. J. Amer. Soc. Hort. Sci. 108:299-303.

Bierman, J., C. Stushnoff, and M.J. Burke. 1979. Differential thermal analysis and freezing injury in cold hardy blueberry flower buds. J. Amer. Soc. Hort. Sci. 104:444-449.

Burke, M. J., L.V. Gusta, H.A. Quamme, C.J. Weiser, and P.H. Li. 1976. Freezing and injury in plants. Annu. Rev. Plant Physiol. 27:507-528.

George, M.F. 1982. Freezing avoidance by supercooling of tissue water in vegetative and reproductive structures of Juniperus virginia, p. 367-377. In: P.H. Li and A. Sakai (eds.). Plant cold hardiness and freezing stress. vol. 2. Academic, New York.

George, M.F. and M.J. Burke. 1977. Cold hardiness and deep supercooling in xylem of shagbark hickory. Plant Physiol. 59:319-325.

George, M. F., M.J. Burke, H.M. Pellett, and A.G. Johnson. 1974. Low temperature exotherms and woody plant distribution. HortScience 9:519522.

Levitt, J. 1956. The hardiness of plants. Academic, New York.

Montano, J. M., M. Rebhuhn, K. Hummer, and H.B. Lagerstedt. 1987. Differential thermal analysis for large-scale evaluation of pear cold hardiness. HortScience 22:1335-1336.

Nus, N. L., J.L. Weigle, and J.J. Schoradle. 1981. Superimposed amplified exothenn differential analysis system. HortScience 16:753-754.

Olien, C.R. 1981. Analysis and improvement of plant cold hardiness. Academic, New York.

Pierquet, P. and C. Stushnoff. 1980. Relationships of low temperature exotherm to cold injury in Vitis riparia Michx. Amer. J. Enol. \& Vitic. $31: 1-6$.

Proebsting, E. L., Jr., and A. Sakai. 1979. Determining $\mathrm{T}_{50}$ of peach flower buds with exotherm analysis. HortScience 14:597-598.
Quamme, H.A. 1974. An exothermic process involved in freezing injury to flower buds of several Prunus species. J. Amer. Soct. Hort. Sci. 99:493500.

Quamme, H.A. 1976. Relationship of low temperature exotherm to apple and pear production in North America. Can. J. Plant Sci. 56:493-500.

Quamme, H.A. 1978. Mechanism of supercooling in overwintering peach flower buds. J. Amer. Soc. Hort. Sci. 103:57-61.

Quamme, H.A. 1983. Relationship of air temperature to water content and supercooling of overwintering peach flower buds. J. Amer. Soc. Hort. Sci. 108:697-701.

Quamme, H.A. 1985. Avoidance of freezing injury in woody plants by deep supercooling. Acta Hort. 18: 11-31.

Quamme, H.A. 1986. Use of thermal analyses to measure freezing resistance of grape buds. Can. J. Plant Sci. 66:945-952.

Quamme, H. A., P.M. Chen, and L.V. Gusts. 1982a. Relationship of deep supercooling to freezing injury in dormant stem tissues of 'Starkrimson Delicious' apple and 'Siberian C' peach. J. Amer. Soc. Hort. Sci. 107:299304.

Quamme, H.A. and L.V. Gusts. 1987. Relationship of ice nucleation and water status to freezing patterns in dormant peach flower buds. HortScience 22:465-467.

Quamme, H. A., R.E.C. Layne, H.O. Jackson, and G.A. Spearman. 1975. An improved exotherm method for measuring cold hardiness of peach flower buds. HortScience 10:521-523.

Quamme, H. A., R.E.C. Layne, and W.G. Ronald. 1982b. Relationship of supercooling to cold hardiness and northern distribution of several cultivated and native Prunus species and hybrids. Can. J. Plant Sci. 62: 137148.

Quamme, H. A., C. Stushnoff, and C.J. Weiser. 1972a. Relationship of the low temperature exotherm to cold injury in apple stem tissue. J. Amer. Soc. Hort. Sci. 97:608-613.

Quamme, H. A., C. Stushnoff, and C.J. Weiser. 1972b. Winter hardiness of blueberry species and cultivars in Minnesota. HortScience 7:500-502.

Quamme, H. A., C.J. Weiser, and C. Stushnoff. 1973. The mechanism of freezing resistance in xylem of overwintering apple twigs. Plant Physiol. 51:273-277.

Rajashekar, C. and M.J. Burke. 1978. The occurrence of deep supercooling in the genera Pyrus, Prunus, and Rosa: A preliminary report, p. 213225. In: P.H. Li and A. Sakai (eds.). Plant cold hardiness and freezing stress: Mechanisms and crop implications. vol. I. Academic, New York.

Rajashekar, C., M.N. Westwood, and M.J. Burke. 1982. Deep supercooling and cold hardiness in genus Pyrus. J. Amer. Soc. Hort. Sci. 107:968972.

Sakai, A. 1965. Survival of plant tissue at super low temperature. III. Relation between prefreezing temperature and degree of frost hardiness. Plant Physiol. 40:882-887.

Sakai, A. and W. Larcher. 1987. Frost survival of plants: Response and adaptation to freezing stress. Springer-Verlag, Berlin.

Warrnund, M. R., M.F. George, and B.G. Cumbie. 1988. Supercooling in 'Darrow' blackberry buds. J. Amer. Soc. Hort. Sci. 113:418-422.

Wisniewski, M., E.N. Ashworth, and K. Schaffer. 1987. The use of lanthanum to characterize cell wall permeability in relation to deep supercooling and extracellular freezing in woody plants: I. Intergenic comparisons between Prunus, Cornus and Salix. Protoplasm 139:105-116.

Wolf, T.K. and R.M. Pool. 1987. Factors affecting exotherm detection in the differential thermal analysis of grapevine dormant buds. J. Amer. Soc. Hort. Sci. 112:520-525. 